\title{
FACTORS ASSOCIATED WITH HEALTH CADRE ABILITY TO PROMOTE HEALTH OF PREGNANT WOMEN IN SLEMAN REGENCY, YOGYAKARTA
}

\author{
Istri Yuliani'), Bhisma Murti'2), Endang Sutisna3), \\ Tedjo Danudjo Oepomo4) \\ 1)Diploma Program of Midwifery, Universitas Respati Yogyakarta \\ 2) Masters Program in Public Health, Universitas Sebelas Maret \\ 3)Department of Public Health, Faculty of Medicine,Universitas Sebelas Maret \\ 4)Department of Obstetrics and Gynecology, Faculty of Medicine, \\ Universitas Sebelas Maret
}

\begin{abstract}
Background: Maternal mortality rate in Indonesia is high, with approximately 305 deaths/100,000 live births. Maternal mortality often occurs because of labor complication. There is a need for improvement in the quality of women health. Health promotion on pregnant women is an effort to increase awareness and ability to control healthy life. Health cadres are expected to improve the quality of maternal health. This study aimed to determine factors associated with health cadre ability to promote the health of pregnant women in Sleman Regency, Yogyakarta.

Subjects and Method: This was an analytic qualitative study with a crosssectional approach, conducted in Sleman Regency, Yogyakarta from February to March 2018. A sample of 269 pregnant women was selected for this study by multistage cluster random sampling technique. The dependent variables were cadre attitude, awareness, and ability to promote the health of pregnant women. The independent variables were education, knowledge, experience, and attitude. The data were collected by questionnaire and analyzed by path analysis.

Results: Factors influencing cadre attitude were education $(b=0.13 ; \mathrm{SE}=0.50$; $\mathrm{p}>0.005)$, knowledge $(\mathrm{b}=0.06 ; \mathrm{SE}=0.13 ; \mathrm{p}>0.005)$, and experience $(\mathrm{b}=0.02$; $\mathrm{SE}=0.05 ; \mathrm{p}>0.005)$. Factors influencing cadre awareness and ability to promote health of pregnant women were $(b=0.55 ; \mathrm{SE}=0.12 ; \mathrm{p}>0.005)$, knowledge $(b=$ 0.94; $\mathrm{SE}=0.28 ; \mathrm{p}<0.001)$, experience $(\mathrm{b}=0.41 ; \mathrm{SE}=0.10 ; \mathrm{p}<0.001)$, attitude $(\mathrm{b}=$ $0.39 ; \mathrm{SE}=0.12 ; \mathrm{p}<0.005)$. Fit model: $\mathrm{p}=0.528 ; \mathrm{GFI}=0.99 ; \mathrm{NFI}=0.99 ; \mathrm{CFI}=1.00$; RMSEA $<0.001$.
\end{abstract}

Conclusion: Factors influencing cadre attitude is education, knowledge, and experience. Factors influencing cadre awareness and ability to promote the health of pregnant women are knowledge, experience, and attitude.

Keywords: education, knowledge, experience, attitude, health promotion, cadres.

\section{Correspondence:}

Istri Yuliani. Diploma III Program of Midwifery, Respati University Yogyakarta, Yogyakarta. Email: istriyuliani1@gmail.com.Mobile: O8122796697. 